\title{
Geodetic Activity for Compatibility of the Unit of Length of Geodetic Bases Koštice (Czech Republic) and Javoriv (Ukraine)
}

\author{
Igor Sevirovic TREVOGO'), Jiř́ LECHNER ${ }^{2)}$, Barbara TORA ${ }^{3)}$, \\ Pavel ČERNOTA ${ }^{4)}$, Hana STAŇKOVÁ ${ }^{5)}$
}

\footnotetext{
1) Prof., Ph.D., National University Lvivska Polytechnika, Mytropolyta Andreia Street 3, Lvov, Halych Raion, Ukraine; email: itrevoho@gmail.com

2) Ing., CSc., Research Institute of Geodesy, Topography and Cartography, Ústecká 98, 25066 Zdiby, Czech Republic; tel.:+420 226802330, email: jiri.lechner@vugtk.cz

3) Prof., dr., hab.inż., AGH University of Science and Technology, Faculty of Mining and Geoengineering, Krakow, Poland; email: tora@agh.edu.pl

4) doc., Ing., Ph.D.; Katedra geodézie a důlního měřictví, Hornicko geologická fakulta Vysoké školy báňské Ostrava, Czech Republic; email: pavel.cernota@vsb.cz

5) doc., Ing., Ph.D.; Katedra geodézie a důlního měřictví, Hornicko geologická fakulta Vysoké školy báňské Ostrava, Czech Republic; email: hana.stankova@vsb.cz
}

http://doi.org/10.29227/IM-2020-01-05

Submission date: $21-12-2019$ | Review date: 01-03-2020

\section{Abstract}

The paper deals with geodetic and metrological activities in the field of length parameter, on the basis of which the uniformity and accuracy of measurements and gauges are ensured also in international extent. The historical role of surveyors in determining the basic unit of length is briefly described. Furthermore, the impact of the application of the laser tracker on the accuracy of determination of the characteristics of the geodetic length standard Koštice (Czech Republic) is evaluated. Based on laboratory tests performed in VUGTK and interlaboratory comparative tests with a leading laboratory in the length parameter in Veisala (Finland), the declared uncertainties of measurement of the VUGTK laboratory were confirmed. These are applied in the metrological traceability of the geodetic length base in Javoriv (Ukraine).

Keywords: geodesy, metrology, measurement accuracy, metrological traceability, geodetic length base

\section{Introduction}

The perfect functioning of the single market in all technical areas, and thus in geodesy, can only be ensured if the rules are harmonized in improving quality management systems, ie by ensuring the uniformity and accuracy of measurements and gauges. Measurement must therefore have a well-defined unit of measurement, an appropriate measurement method must be used, the necessary measuring means must be available and the human factor of the person making the measurement must also be taken into account.

\section{Definition of length and use of length parameter in geo-} detic practice

According to the definition of the basic units of the SI system, the meter is the distance traveled by light in vacuum in $1 / 299792458 \mathrm{~s}$.

In geodetic practice the length parameter is used not only to measure direct distances, but also in combination with angles and directions to determine the position of the objects in space. For this purpose, rangefinders (optical, electronic, laser, ultrasonic, etc.) are used, which are combined with an angle gauge (theodolite) to form total stations.

For the field of metrology and geodesy there are also normative acts at the government decree level in the Czech Republic concerning the issue of requirements for measuring instruments [1] and mandatory coordinate reference systems [2].
From the literature we know about the imperial Decree of 1661, which already addressed the issue of quality as follows:

First of all, with regard to weight and size,

be careful before everyone

to keep justice.

This quote illustrates the long tradition of metrology in Czech lands. Regulation applies to the field of exchange of goods. Currently, metrological requirements are associated, first of all, with ensuring the uniformity and accuracy of measuring instruments and the measurements themselves, not only in business, but also in production activities.

\section{Basic characteristics determined for rangefinders \\ Calibration of electronic rangefinders of geodetic total stations serves to verify their metrological parameters and to determine additive and multiplicative constants. Traditional- ly, terrain length bases are used for this purpose, which make possible testing of long length measurements in real condi- tions. The top current electronic rangefinders have a measure- ment accuracy below the threshold}

$Q(1 \mathrm{~mm}+1 \mathrm{ppm} . \mathrm{D})$, where $D$ is the measured distance in $\mathrm{km}$. For example, the Leica Nova TS60 Q $(0,6 \mathrm{~mm}+1,0 \mathrm{ppm}$. D) and the Trimble S9 HP

$Q(0,8 \mathrm{~mm}+1,0 \mathrm{ppm} . \mathrm{D})$ are available. 


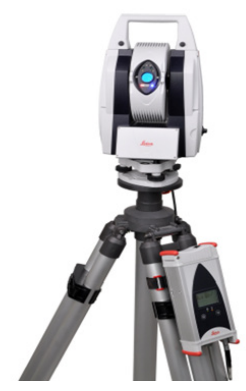

Fig. 1. Laser tracker Leica AT 401

Rys. 1. Miernik laserowy AT 401

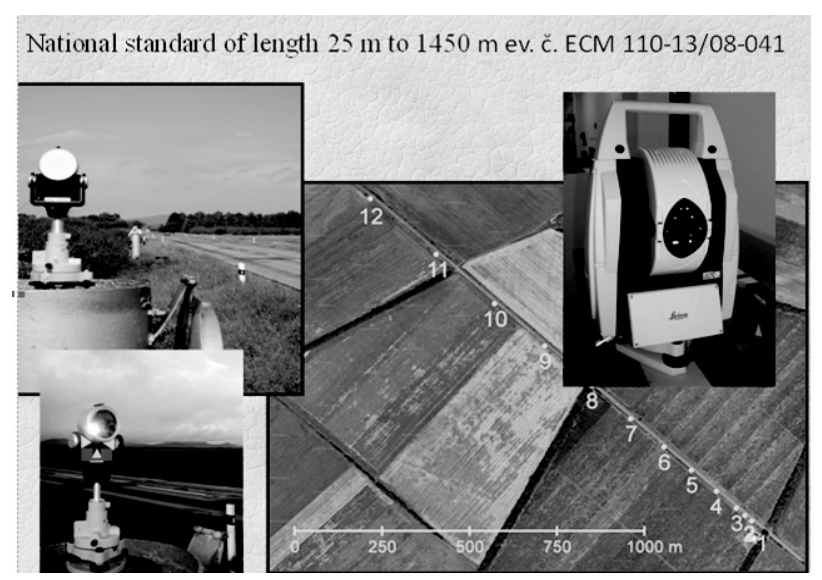

Fig. 2. Geodetic lenght base Koštice

Rys. 2. Podstawa długości geodezyjnej Koštice

A stable off-road base with accurate reference lengths is required to verify rangefinders during calibration. One possible way how to calibrate geodetic bases is to use a laser tracker. These devices are typical by the accuracy of micrometers, but usually have a limited range of meters. Since 2011 Research Institute of Geodesy, Topography and Cartography, p.r.i. (VUGTK) owns laser tracker Leica AT401, whose parameters are most suitable in terms of geodesy. This instrument has a specified measuring range up to $160 \mathrm{~m}$ with a standard deviation of $5 \mu \mathrm{m}$ (for lengths up to $80 \mathrm{~m}$ ). VÚGTK, as an associated laboratory of the Czech Metrology Institute, manages the geodetic base Koštice, declared as the State Standard of $25 \mathrm{~m}$ to $1450 \mathrm{~m}$ in 2008.

\section{Practical examples of the need to know the characteris- tics of precise instruments}

When performing publicly useful geodetic works, officially authorized (certified) geodetic engineers confirm compliance with the metrological requirements. This confirmation "The content and accuracy meets the requirements of legistation". In the case of small private firms that have not introduced a quality management system and are not subcontractors in the framework of public procurement, it is still very difficult to prove the metrological compliance of measuring instruments, and in many cases they refer only to the accuracy declared in the technical passport of the measuring instrument. In geodesy, lengths, horizontal and vertical angles are measured mainly. Angles are characterized by a standard deviation independent on the distance to the target. The term "standard deviation" or "standard error", usually characterizes the accuracy of measurements of a single reception (ISO
17123). At present, theodolites or total stations with declared standard error for measuring horizontal directions and zenith distances. To express the accuracy of length measurements, an additional term shall be added to the absolute term, depending on the measured length value, in the form:

$\sigma_{\mathrm{d}}=\mathrm{a}(\mathrm{mm})+\mathrm{b} \mathrm{ppm} \cdot \mathrm{d}(\mathrm{km})$

e.g. at $2 \mathrm{~mm}+2 \mathrm{~mm}$ per $1 \mathrm{~km}$, a line $500 \mathrm{~m}$ long the standard deviation is $3 \mathrm{~mm}$. With repeated measurements of the same value, we obtain results that differ in a certain sense. Each re-measured value contains a valid error, which reduced or increased the measurement result in compare with the nominal (projected) value $\mathrm{L}$ of the specific measured value. An authorized (certified) surveyor engineer, when performing cartographic and geodetic works and evaluating the accuracy of measurement, must take into account:

1) the value of the tolerance (for production, installation, operation, etc.), permissible deviations or deviations, which are given in some initial or new technical standards. The required accuracy parameters for individual elements are given in technical specifications, in project documentation or in contract documentation;

2) the values of the metrological traceability of the measuring device to the standard;

3) inaccuracy of the measurement technology and taking into account the influence of environmental conditions - the 


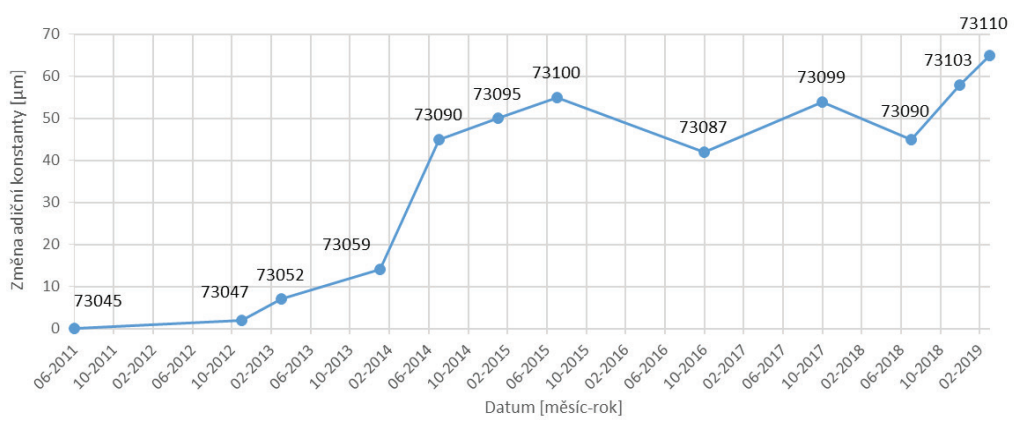

Fig. 3. Development of the addition constant of the test kit Rys. 3. Opracowanie stałej dla zestawu testowego

Tab. 1. Results of interlaboratory comparison at the geodetic base in Nummela Tab. 1. Wyniki badań międzylaboratoryjnych w bazie geodezyjnej w Nummela

\begin{tabular}{|l|c|}
\hline Zkušebni položka: & Geodetická délková základna Nummela (Finsko) \\
\hline Výrobce: & National Land Survey of Finland, Finnish Geospatial Research Institute \\
\hline Typ: & 6 pozorovacích piliřủ ve vzdálenostech 0, 24, 72, 216, 432 a 864 m \\
\hline Výrobni číslo: & neuvedeno \\
\hline
\end{tabular}

\begin{tabular}{|c|c|c|c|c|c|c|c|}
\hline $\begin{array}{l}\text { Pilíř č. - Piliřr č. } \\
\text { (označeni FIN) }\end{array}$ & $\begin{array}{l}x_{\text {lab }} \\
(\mathrm{mm})\end{array}$ & $\begin{array}{l}U_{\text {lab }} \\
(\mathrm{mm})\end{array}$ & $\begin{array}{l}X_{\text {ref }} \\
(\mathrm{mm})\end{array}$ & $\begin{array}{l}U_{\text {ref }} \\
(\mathrm{mm})\end{array}$ & $\begin{array}{c}\mathbf{x}_{\text {lab }}-\mathbf{x}_{\text {ref }} \\
(\mathrm{mm})\end{array}$ & $E_{n}$ & Hodnoceni \\
\hline $1-2(0-24)$ & 24033,6 & 0,4 & 24033,25 & 0,35 & 0,35 & 0,66 & A \\
\hline $1-3(0-72)$ & 72015,2 & 0,4 & 72015,45 & 0,35 & $-0,25$ & $-0,47$ & A \\
\hline $1-4(0-216)$ & 216055,2 & 0,8 & 216055,66 & 0,35 & $-0,46$ & $-0,53$ & A \\
\hline $1-5(0-432)$ & 432099,7 & 1,2 & 432099,14 & 0,35 & 0,56 & 0,45 & A \\
\hline $1-6(0-864)$ & 864133,3 & 1,4 & 864132,82 & 0,35 & 0,48 & 0,33 & A \\
\hline $2-3(24-72)$ & 47982,1 & 0,4 & 47982,20 & 0,35 & $-0,10$ & $-0,19$ & A \\
\hline $2-4(24-216)$ & 192022,1 & 0,8 & 192022,41 & 0,35 & $-0,31$ & $-0,36$ & A \\
\hline $2-5(24-432)$ & 408066,6 & 1,0 & 408065,89 & 0,35 & 0,71 & 0,67 & A \\
\hline $2-6(24-864)$ & 840100,4 & 1,4 & 840099,57 & 0,35 & 0,83 & 0,58 & A \\
\hline $3-4(72-216)$ & 144040,5 & 0,6 & 144040,22 & 0,35 & 0,28 & 0,40 & A \\
\hline $3-5(72-432)$ & 360084,3 & 1,0 & 360083,70 & 0,35 & 0,60 & 0,57 & A \\
\hline $3-6(72-864)$ & 792118,4 & 1,4 & 792117,37 & 0,35 & 1,03 & 0,71 & A \\
\hline $4-5(216-432)$ & 216042,8 & 0,8 & 216043,48 & 0,35 & $-0,68$ & $-0,78$ & A \\
\hline $4-5(216-864)$ & 648077,9 & 1,2 & 648077,16 & 0,35 & 0,74 & 0,59 & A \\
\hline $5-6(432-864)$ & 432034,0 & 1,2 & 432033,68 & 0,35 & 0,32 & 0,26 & A \\
\hline
\end{tabular}

$\mathbf{x}_{\text {lab }}, \mathbf{x}_{\text {ref }}$

uncertainty of the technology. This technology is selected before measurements after analyzing the possible accuracy in such a way that the required value of the observed parameter is confirmed as a result. In case the source documentation is in a foreign language, it is important to carefully approach the translation of the terms: tolerance and rejection, as the mistake made can lead to unpleasant consequences. One way to prevent such cases is to develop multilingual digital terminology dictionaries.

\subsection{Calibration of measuring devices}

In metrology, the accuracy characteristics are expressed by the standard uncertainty $\mathrm{u}$ of the measurement results and the expanded uncertainty $U$. The expanded measurement uncertainty is the product of the standard measurement uncertainties and the expansion coefficient $\mathrm{k}=2$, which, with a normal distribution, corresponds to a coverage probability of approximately $95 \%$. The standard measurement uncertainty is determined in accordance with document [11]. To determine the metrological correspondence of individual quantities, standards with established metrological parameters - uncertainties are used. In industry it is often necessary to achieve the highest accuracy. In this case, a direct connection is used, i.e. determination of metrological correspondence of the range finder with a laser interferometer directly in the me- trological laboratory. Using the main standard of the VUGTK calibration laboratory, the metrological compliance of the tracker Leica AT401 is also determined (Fig. 1), i.e. so-called total additive and multiplicative device constants. The expected accuracy of measuring lines by the tracker Leica AT401 is expressed by the equation for the standard uncertainty

$\mathrm{u}=\mathrm{Q}(0,012 ; 0,001 \bullet \mathrm{L}(\mathrm{m})) \mathrm{mm}$.

Actual error consists of gross errors and inevitable errors, i.e. random $\left(\Delta_{\mathrm{i}}\right)$ and systematic $\left(\mathrm{c}_{\mathrm{i}}\right)$ errors. In connection with the requirement to eliminate gross errors, the actual error can be expressed as

$\varepsilon_{\mathrm{i}}=\Delta_{\mathrm{i}}+\mathrm{c}_{\mathrm{i}}$,

where the systematic component ci is to some extent interdependent (correlated) and can be suppressed, for example, by calibration, i.e. by comparison with the standard. In the case of random errors, we assume that the size of the errors and their sign correspond to the normal distribution. For length measurements using electro-optical rangefinders, measurement accuracy can be expressed by the standard deviation of the length measurement in $\mathrm{mm}$ 


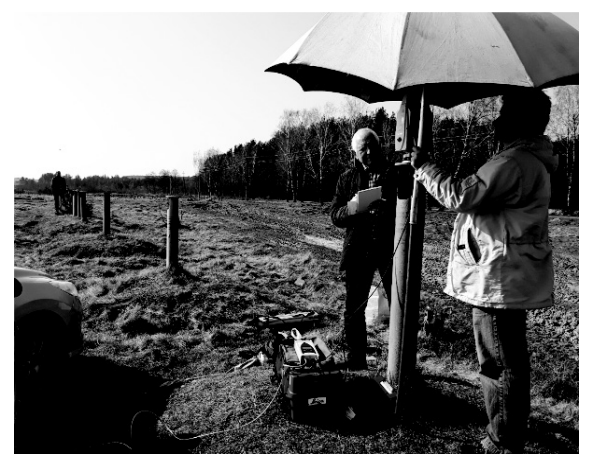

Fig. 4. Tracker Leica AT401 measurements at geodetic base Javoriv

Fig. 4. Pomiary analizatorem Leica AT401 w bazie geodezyjnej Javoriv

Tab. 2. Demonstration of measured data with tracker Leica AT 401

Tab. 2. Dane pomiarowe uzyskane za pomocą miernika Leica AT 401

\begin{tabular}{|c|c|c|c|c|}
\hline \multicolumn{4}{|c|}{ DT_20190408T081105javorov1.tot - Notepad } & 1201 \\
\hline \multicolumn{5}{|c|}{ File Edit format View Help } \\
\hline 6638154758 & 16.0404179633 & 0.0000801800 & 0.0003171852 & 0.0000025395 \\
\hline 6635316858 & 16.0404219122 & 0.0000544000 & 0.0002078110 & 0.0000013598 \\
\hline 5389548602 & 17.0394695254 & 0.0000490731 & 0.0003448840 & 0.0000013769 \\
\hline 5389049242 & 17.0394724246 & 0.0000992470 & 0.0001238337 & 0.0000025786 \\
\hline 5389237119 & 17.0394756487 & 0.0000513627 & 0.0001753664 & 0.0000017720 \\
\hline 5387786593 & 17.0394775149 & 0.0000572468 & 0.0001897965 & 0.0000018523 \\
\hline 5389011752 & 17.0394763356 & 0.0001302523 & 0.0002310764 & 0.0000025721 \\
\hline 5389688689 & 17.0394752109 & 0.0000863757 & 0.0001114786 & 0.0000013178 \\
\hline 5389478443 & 17.0394761274 & 0.0000269489 & 0.0000676270 & 0.0000015246 \\
\hline 648866 & 17.0394751610 & 0.0000480987 & 0.0001369357 & 0.0000019916 \\
\hline 662431 & 17.0394811011 & 0.0000518050 & 0.0001454680 & 0.0000008770 \\
\hline 5388701673 & 17.0394836954 & 0.0000347961 & 0.0001901226 & 0.0000022807 \\
\hline 4115299049 & 18.0342614894 & 0.0000565666 & 0.0001758172 & 0.0000018264 \\
\hline 4115344751 & 18.0342630834 & 0.0000575337 & 0.0001734704 & 0.0000020565 \\
\hline 4115667460 & 18.0342662076 & 0.0000516148 & 0.0001626304 & 0.0000019799 \\
\hline 4115362070 & 18.0342641681 & 0.0000702485 & 0.0002428036 & 0.0000016402 \\
\hline 4115082995 & 18.0342662326 & 0.0001386044 & 0.0004394433 & 0.0000015108 \\
\hline 4115178749 & 18.0342721267 & 0.0000394152 & 0.0001911776 & 0.0000024717 \\
\hline 4117684059 & 18.0342714019 & 0.0000608163 & 0.0001661730 & 0.0000022398 \\
\hline 4117653307 & 18.0342734514 & 0.0000819627 & 0.0003318413 & 0.0000021710 \\
\hline 4117995361 & 18.0342688926 & 0.0000834797 & 0.0003045217 & 0.0000022024 \\
\hline 4118745052 & 18.0342618532 & 0.0000799006 & 0.0002207723 & 0.0000017263 \\
\hline 3572738282 & 19.0296962025 & 0.0000673282 & 0.0002440101 & 0.0000031224 \\
\hline 3570666459 & 19.0297007263 & 0.0001072328 & 0.0004896569 & 0.0000021385 \\
\hline 3571507286 & 19.0297023332 & 0.0000819331 & 0.0002817511 & 0.0000024593 \\
\hline 3571861944 & 19.0297029330 & 0.0001094235 & 0.0002603692 & 0.0000019253 \\
\hline 3571183304 & 19.0296950351 & 0.0000749601 & 0.0000753128 & 0.0000011832 \\
\hline 3571578041 & 19.0296975037 & 0.0001052431 & 0.0003395736 & 0.0000021370 \\
\hline 3571328548 & 19.0296955542 & 0.0000820788 & 0.0001874065 & 0.0000013916 \\
\hline 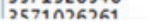 & bogeoonan & $\cap$ กMN11 2 KAN1 & ก กาก 2777018 & כח \\
\hline
\end{tabular}

$\sigma_{\mathrm{d}}=\mathrm{a}(\mathrm{mm})+\mathrm{b} \mathrm{ppm} \cdot \mathrm{d}(\mathrm{km})$

From a practical example of a completely new device without indicating its type, it is assumed that the accuracy of the length measurement corresponds to the technical conditions of the device $(1+1,5 \mathrm{ppm})$, respectively for measurements without a prism $(2+2 \mathrm{ppm})$. In real atmospheric conditions, the measurement accuracy was determined from the point of view of prism measurements $(1,3+3,7 \mathrm{ppm})$ in $\mathrm{mm}$ and from the point of view of measurements without a prism $(2,4+2,7$ $\mathrm{ppm}$ ) for a maximum length of $200 \mathrm{~m}$ in $\mathrm{mm}$. In the case of additional and multiplicative constants, determined during processing, the accuracy characteristic for measurement with a prism changes to a value $(0,4+0,7 \mathrm{ppm})$ in $\mathrm{mm}$. From the given real example, the need for standards for determining the accuracy of measurements or for demonstrating a certain parameter of geometric accuracy follows. Based on the above facts, the result of the calibration activity can be attributed to the determination of the external accuracy of the measurements, that is, provided that individual measurements are evaluated relative to the true values of the standard.

\section{Technical and economic justification of the need for} a standard
Since the 1980s electronic rangefinders in the field of geodesy and land registry have been used in the Czech Republic.

The technical development of these instruments has allowed a change in the resolution of the previous $1 \mathrm{~cm}$, respectively $5 \mathrm{~mm}$, changed to millimeter, respectively tenths of millimeter. These circumstances and request formulated in the Government Resolution on the Concept of the Development of the Metrological System of the Czech Republic with Equivalence with the System in the European Union led to the inclusion of the solution of the task within the Metrology Development Program of the Office for Technical Standardization, Metrology and State Testing (UNMZ) for the announcement of the national standard of long lengths.

\section{History of the Koštice Standard}

Standardization of lengths from $25 \mathrm{~m}$ to $1450 \mathrm{~m}$ was resolved by the approval of the national standard (SE) in 2008. Until that time, metrological traceability was solved for rangefinders using geodetic bases realized in individual regions. Due to technical developments, the resolution of these measuring instruments has improved over time (from the original value of $1 \mathrm{~cm}$ to the current standard value of $0,1 \mathrm{~mm}$ ). At the same time, the requirements for compliance with construction tolerances have been tightened and, in 
particular as a result of EU integration, the requirements for stricter criteria in terms of metrology have increased. Given the existence of metrological continuity of rangefinders, it was necessary to solve a matter acceptable in terms of labor and accuracy. These circumstances led to the realization of a new composition of SE lengths.

\section{Description of the Koštice Standard}

The national standard of lengths of $25 \mathrm{~m}$ to $1450 \mathrm{~m}$ consists of the following items:

- field geodetic base Koštice (12 stabilized pillars with forced centering), s/n ECM 110-13/08-041,

- laser interferometer $633 \mathrm{~nm}$ LIMTEK,

- tracker Leica AT401,

- Leica NOVA MS50 multi-station (total station).

Longitudinal traceability of rangefinders is performed on the geodetic base Koštice.

Geodetic lenght base Koštice: standard uncertainty of determination of length parameters $\mathrm{u}=\mathrm{Q}[165 ; 0,8 \bullet \mathrm{L}(\mathrm{m})] \mu \mathrm{m}$.

\section{Calculation of measuring capability of calibration of state standard}

In view of some instability of the state standard itself, this aspect is considered when calculating the measurement capability of the state standard calibration.

\subsection{Additive constant of the tracker Leica AT401 and RRR 1.5 in prism}

The additive constant is a mathematical correction of the measured length that takes into account the mechanical and electronic effects of the rangefinder and the mechanical effects of the prism. All of the above-mentioned effects are often tested together and the measurement kit is therefore treated as an instrument-prism assembly. The additive constant of the tracker Leica AT401 (s/n 576371) and the Leica RRR 1.5 in spherical prism ( $/ \mathrm{n} 8058)$ were tested. The later purchased RRR 1.5 in prism ( $/$ n 575784) has the specified centricity even lower $(3 \mu \mathrm{m})$ and is tested by comparison with prism $\mathrm{s} / \mathrm{n}$ 8058 on the selected length base.

The first determination of the constant was made by the instrument manufacturer. The usual procedure for checking or compensating the additive constant is done by means of a test that is implemented in the manufacturer's official control software called Leica TrackerPilot. Even in this application, however, the measurement methodology (eg change of base length from 1,5 $\mathrm{m}$ to $2,0 \mathrm{~m}$ ) and data evaluation (eg change of tolerance from $10 \mu \mathrm{m}$ to $5 \mu \mathrm{m}$ ) have been changed. The test is usually performed repeatedly and the variation of the results of the constant is monitored for its multiple determination. Fig. 3 shows graphically the development of the constant in the period 06/2011 (determined by the manufacturer Leica) to $02 / 2019$ (determined in the framework of the thesis of Ing. Petr Kůdela). From the graph we can deduce the approximate time interval needed for retesting and determining the constant, if we know the requirement for real measurement accuracy for specific geodetic activities.

\subsection{Interlaboratory Comparison (ILC)}

The issue of traceability to foreign Laboratory of the National Metrology was planned for 2018 (June) with the National Land Survey of Finland, the Finish Geospatial Research Institute (FGI), the Department of Geodesy and Geodynamics, the National Standards Laboratory, Geodeetinrinne 2, FI-02430 Masala, Finland. Bilateral comparative tests in the parameter of long lengths took place from 25th to 29th June 2018 at a geodetic base in Finland - Nummela. The actual comparative measurement was carried out on the base with lengths of $24 \mathrm{~m}, 48 \mathrm{~m}, 72 \mathrm{~m}, 144 \mathrm{~m}, 192 \mathrm{~m}, 216 \mathrm{~m}, 360 \mathrm{~m}$, $408 \mathrm{~m}, 432 \mathrm{~m}, 648 \mathrm{~m}, 792 \mathrm{~m}, 840 \mathrm{~m}$ and $864 \mathrm{~m}$. These were measurements of oblique lengths between the pillars with forced centering. Tracker Leica AT401 and total station Leica MS50 were used for the tests. Based on the measured quantities, these were corrected by corrections for the difference in height of the instrument and the prism, and corrections for the temperature and pressure of the measurement environment were introduced into the measured data.

The lengths of $24 \mathrm{~m}, 47 \mathrm{~m}, 72 \mathrm{~m}$ and $144 \mathrm{~m}$ were repeatedly measured with the tracker Leica AT401 on several days. All possible lengths of the standard were repeatedly measured over several days with the MS 50. Based on the evaluation of measured lengths by an independent and certified organization (Czech Metrology Institute), an overall evaluation of the bilateral international interlaboratory comparison was carried out in August 2018, the results of which are shown in Table 1 . The evaluation shows that all considered uncertainties of VUGTK were confirmed with sufficient reserve.

\subsection{Geodetic length base Javoriv (Ukraine)}

On the basis of a contract between the National University Lvivska Polytechnika and VUGTK and a long-term cooperation between the two institutions, measurements were made in April 2019 on a part of the geodetic length base of the Javoriv geodetic polygon. The measurements were carried out with the tracker Leica AT401. Based on the measured values, these were corrected by corrections for the difference in height of the instrument and prism and corrections for the temperature and pressure of the measuring environment were introduced into the measured data.

Based on an example of the measured data in Table 2, the measurement accuracy of the tracker Leica AT401 at the Javoriv geodetic base can be inferred, for example, for a length of $18 \mathrm{~m}$, the measurement was $261 \mu \mathrm{m}$ - minimum value and $273 \mu \mathrm{m}$ maximum value. In 2020 , it is planned to complete measurements on the geodetic base using the tracker Leica AT 401 and total station Leica MS 50 with the uncertainty

$\mathrm{u}=\mathrm{Q}[165 ; 0,8 \cdot \mathrm{L}(\mathrm{m})] \mu \mathrm{m}$.

The aim of these measurements is to ensure the requirements of European legislation in the framework of quality management, ie to meet the conditions of uniformity and accuracy of measuring instruments and measurements while achieving complete compliance.

\section{Conclusion}

Ensuring uniformity and accuracy of measurements and gauges is an important aspect of achieving of mutual recognition of national standards and measurement certificates is- 
sued by national metrology institutions. This has become a requirement of European standards and is a prerequisite for product safety and quality, competitiveness, removal of technical barriers to trade, consumer protection and other public interests. The VÚGTK calibration laboratory, based on the laboratory work carried out and interlaboratory comparisons with a leading European laboratory, has proven its measuring capabilities, which it also applies internationally.

\section{Literatura - References}

1. Nařízení vlády č. 120/2016 Sb. o posuzování shody měřidel při jejich dodávání na trh.

2. Nařízení vlády č. 430/2006 Sb. o stanovení geodetických referenčních systémů a státních mapových děl závazných na území státu a zásadách jejich používání, ve znění nařízení vlády č. 81/2011 Sb., Zákon č. 200/1994 Sb., o zeměměřictví a o změně a doplnění některých zákonů souvisejících s jeho zavedením, v platném znění.

3. Zákon o metrologii č. 505/1990 Sb., ve znění zákona č. 119/2000 Sb., zákona č. 137/2002 Sb., a zákona č. 13/2002 Sb., v platném znění.

4. Vyhláška č. 264/2000 Sb. o základních měřicích jednotkách a ostatních jednotkách a o jejich označování, v platném znění.

5. ISO 17123-1. Optics and optical instruments - Field procedures for testing geodetic and surveying instruments Part 1: Theory

6. ISO 17123-3. Optics and optical instruments - Field procedures for testing geodetic and surveying instruments Part 3: Theodolites

7. ISO 17123-4. Optics and optical instruments - Field procedures for testing geodetic and surveying instruments Part 4: Electro-optical distance meters (EDM instruments)

8. ISO 17123-5. Optics and optical instruments - Field procedures for testing geodetic and surveying instruments Part 5: Electronic tacheometers

9. EN ISO/IEC 17025:2018 General requirements for the competence of testing and calibration laboratories

10. EA-04/02 M:2013 EA-04/02 M: 2013. Methodology for the expression of measurement uncertainties during calibrations.

\section{Badania geodezyjne zgodności jednosetk długości baz geodezyjnych \\ Koštice (Republika Czeska)i Jaworów (Ukraina)}

Artykuł dotyczy badań geodezyjnych i metrologicznych $w$ zakresie określenia parametru długości, na podstawie których zapewniona jest równoważność i dokładność pomiarów w wymiarze międzynarodowym. Opisano krótko historyczna role geodezji w określaniu podstawowych jednostek długości. Omówiono wpływ zastosowania analizy laserowego na dokładność oznaczania długości geodezyjnej w miejscowości Koštice (Republika Czeska). Na podstawie badań laboratoryjnych przeprowadzonych w VUGTK i międzylaboratoryjnych testów porównawczych $z$ wiodącym laboratorium pod względem parametru długości $w$ Veisala (Finlandia), potwierdzono deklarowana niepewność pomiaru w laboratorium VUGTK. Przedstawiono wyniki pomiarów geodezyjnych w analizie metrologicznej pomiarów geodezyjnych w Jaworowie (Ukraina).

Słowa kluczowe: geodezja, metrologia, dokładność pomiaru, identyfikacja metrologiczna, podstawa długości geodezyjnej 